\title{
Inter-team variability in game play under critical game scenarios: a study in high-level men's volleyball using social network analysis \\ Variabilidad entre equipos en el juego bajo escenarios críticos de juego: un estudio en voleibol masculino de alto nivel utilizando el análisis de redes sociales
}

João Bernardo Martins, José Afonso, Ademilson Mendes, Letícia Santos, Isabel Mesquita

University of Porto (Portugal)

\begin{abstract}
Critical scenarios are highly relevant to match analysis because they contribute to a better understanding of performance and provide essential information about team evolution. The goal of this study was to investigate inter-team variability in high-level men's volleyball during critical game scenarios (i.e., non-ideal setting conditions). Ten matches of the Men's 2019Volleyball Nations League Finals (Russia, USA, Poland, Brazil, Iran, France) were analyzed ( $n=649$ plays). Six independent Eigenvector Centrality networks were created ( 632 nodes; 3507 edges) using Social Network Analysis. When playing under critical scenarios the top two ranked teams differed in side-out attack. Specifically, the USA presented quick attacks, mainly in zone 4, using both the strong attack and exploration of the block. Conversely, Russia presented a game with high attack tempos and strong attacks. The USA and Russia also differed from Poland and Brazil in their approach to the game, the latter two teams using a varied attack (between strong, exploited, and directed attacks). After one error in attack, most teams presented a game style characterized by strong attacks, although Russia played using exploration of the block. The study shows teams competing at the same competitive level have differences in game patterns. The variability in approaches to the attack in critical scenarios (e.g., under non-ideal setting conditions and/or after consecutive attack errors) revealed that teams find different solutions for similar problems. Findings imply that match analysis should focus on exploring inter-team differences in gameplay while being cautious when interpreting aggregate data.
\end{abstract}

Keywords: performance analysis; match analysis; team sports; game patterns.

Resumen. Los escenarios críticos son muy relevantes para el análisis de partidos porque contribuyen a una mejor comprensión del rendimiento y proporcionan información esencial sobre la evolución del equipo. El objetivo de este estudio fue investigar la variabilidad entre equipos en el voleibol masculino de alto nivel durante escenarios críticos de juego (principalmente en condiciones de colocación no ideales). Se analizaron diez partidos de las Finales de la Liga de Naciones deVoleibol Masculino 2019 (Rusia, Estados Unidos, Polonia, Brasil, Irán, Francia) ( $n=649$ jugadas). Se crearon seis redes de centralidad de autovector independientes ( 632 nodos; 3507 bordes) utilizando el análisis de redes sociales. Cuando se jugaba en escenarios críticos, los dos mejores equipos clasificados diferían en ataque lateral. Específicamente, los Estados Unidos presentaron ataques rápidos, principalmente en la zona 4, utilizando tanto el fuerte ataque como la exploración del bloqueo. Por el contrario, Rusia presentó un juego con altos ritmos de ataque y ataques fuertes. Los Estados Unidos y Rusia también se diferenciaron de Polonia y Brasil en su enfoque del juego, los dos últimos equipos utilizando un ataque variado (entre ataques fuertes, explotados y dirigidos). Después de un error en ataque, la mayoría de los equipos presentaron un estilo de juego caracterizado por ataques fuertes, aunque Rusia jugó utilizando la exploración del bloque. El estudio muestra que los equipos que compiten al mismo nivel competitivo tienen diferencias en los patrones de juego. La variabilidad en los enfoques del ataque en escenarios críticos (en condiciones de colocación no ideales y/o después de errores de ataque consecutivos) reveló que los equipos encuentran diferentes soluciones para problemas similares. Los hallazgos implican que el análisis de partidos debe centrarse en explorar las diferencias entre equipos en el juego y, al mismo tiempo, ser cauteloso al interpretar los datos agregados.

Palabras clave: análisis de rendimiento; análisis de partidos; deportes de equipo; patrones de juego.

\section{Introduction}

Performance analysis refers to the interpretation and analysis of performance indicators to optimize the training process and improve match outcomes (Mike Hughes, 2004). In turn, match analysis refers to the process of recording game actions, both individual and collective, in real performance contexts. Match analysis is valuable for extracting information about the behavior of teams and their opponents (Mike Hughes \& Franks,

Fecha recepción: 20-07-21. Fecha de aceptación: 02-10-21 João Bernardo Martins

joao_10z@hotmail.com
2008) and consequently can be used to examine variability in performance between teams. Inter-team variability refers to the differences that coexist with stability or regularity of performance within teams (Higham, Hopkins, Pyne, \& Anson, 2014), and is a relevant theme in performance analysis and match analysis because it allows coaches to be better prepared to use approaches and tools to explore behaviors between teams (Sarmento et al., 2014). So far, the study of variability in performance analysis has mostly focused on physical and physiological responses (Dong, 2016; Hill-Haas, Coutts, Rowsell, \& Dawson, 2008), but can be extended to the tactical aspects of performance.

Most investigations applying match analysis focus on 
average performance values (Castellano \& Pic, 2019; Lorenzo-Martínez, Rey, \& Padrón-Cabo, 2019), i.e., values that aggregate all teams or groups of teams. Models based on averages may be non-representative of reality because they do not capture how, or to what extent, individual performances differ from the group average (Gryc, Zahalka, Maly, Mala, \& Hrasky, 2015). Therefore, knowledge about inter-team variability remains incomplete with few studies. Analysis of interteam variability is necessary because it provides a more rounded understanding of the complexities of high-level performance and, consequently, gives coaches important information on how physical, tactical-technical, and psychological performances differ (Gregson, Drust, Atkinson, \& Salvo, 2010). Past studies focused on interteam variability have mostly considered the differences between competitive levels (Méndez, Gonçalves, Santos, Ribeiro, \& Travassos, 2019; Ramos, Coutinho, Silva, Davids, Guimarães, et al., 2017; Yi, Gómez, Liu, \& Sampaio, 2019) and, to a much lesser extent, variability in performance within the same competitive level (Castelão, Garganta, Afonso, \& Da Costa, 2015; Laporta et al., 2021).

Studies focused on variability at different competitive levels have shown, for example, differences in the game system and tactical behaviors of elite and non-elite volleyball teams (Ramos, Coutinho, Silva, Davids, Guimarães, et al., 2017). Specifically, in this study the best non-elite teams showed more unpredictability in their standards of play compared to the best of elite teams due to the greater balance between the elite teams. Research on football, a sport where teams share the same space/area, has studied the influence of interpersonal tasks and context variables on the game actions of teams competing in different championships (Méndez et al., 2019). Studies have uncovered how game actions influence game variables and performance in different teams competing in the same elite futsal competition (Yi et al., 2019). Studies considering variability within the same competitive level are far less common. Only two studies of inter-team game patterns of the same level were found (Castelão et al., 2015; Laporta et al., 2021). The first focused on the offensive actions of high-level football teams and the second aimed to understand the different game models existing at the same competitive level in volleyball. In a very recent study, Laporta et al. (2021) showed that: (i) all teams presented different game approaches, regarding setting conditions, serve, as well as attack zones and tempos; (ii) still, attack efficacy was not associated with the game model. The authors therefore exposed that there is a large range of distinct game approaches even within high-level teams. Coaches may therefore explore their teams' features creatively, as there are various ways of achieving success. In summary, the match analysis literature on performance variability has mainly explored variability arising across competitive levels and/or gender-related differences, while interteam variability within the same competitive level remains largely unexplored.

It is likely that not all game scenarios are equally suited to highlighting inter-team differences. Game scenarios reflect a set of variables and conditions that are functionally connected (Laporta, Afonso, Valongo, \& Mesquita, 2019), and these scenarios can occur at critical or non-critical moments (Batista et al., 2019). We argue that scenarios with non-ideal game conditions are well suited for exploring the idiosyncrasies of each competitor. Non-ideal setting conditions in volleyball (i.e., where the team has a poor quality first touch and is consequently in a situation of high difficulty for the construction of the attack) offer one possible avenue for this analysis, as advocated by Laporta et al. (2021). Another possibility for this type of analysis in volleyball is when errors occur consecutive to the attack because this puts the team in a pressure situation, as supported in literature (Martins, Afonso, Coutinho, Fernandes, \& Mesquita, 2021).

Social Network Analysis (SNA) is an appropriate tool for studying inter-team variability in match analysis because it offers an understanding of the interactions between relevant variables. Within SNA, interaction networks highlight the degree of relationships and specificity in the different game phases, helping to recognise the most influential game actions (Wäsche, Dickson, Woll, \& Brandes, 2017). Although the most widely used measure in SNA is Degree Centrality, Eigenvector Centrality has the benefit of weighting direct connections based on their indirect connections (Bonacich, 2007). Research using SNA allows MA studies to explore the behaviours of individual players, but it is also possible to apply the same tools to analyse relationships between game actions, sequences, and game complexes, a strategy that has been successfully applied in the context of volleyball (Hurst et al., 2016; Laporta et al., 2019).

Thus, the goal of the present study was to investigate inter-team variability in critical game scenarios within the same competitive level — specifically in high-level men's volleyball — using Social Network Analysis. 


\section{Material and methods}

\section{Participants}

We analyzed all the games of the final phase of the men's 2019 Volleyball Nations League (VNL), which comprised 6 teams (Russia, the United States, Poland, Brazil, Iran, and France) divided into two groups and ten matches ( 35 sets). A total of 649 plays under critical game scenarios were examined. We defined critical game scenarios as (a) attack actions under ideal or nonideal setting conditions (giving major focus to non-ideal setting conditions) and after consecutive attack errors; and (b) critical moments are more decisive than noncritical moments, due to their weight at the time of play (Hughes, Landridge, \& Dawkin, 1998; SánchezMoreno, Mesquita, Afonso, Millán-Sánchez, \& Ureña, 2018); in this way the critical moment was defined as the attack from the second technical time-out (i.e., 16 points) onwards (from 1st to 4th sets), because it is a moment that usually triggers greater unbalanced between teams and because it was the last international competition that used technical time-outs (at 8 and 16 points) or after the tenth point (only in the 5th set) (Fernández-Echeverria et al., 2013; Marcelino, Mesquita, \& Sampaio, 2011).We focus on outside hitters $(\mathrm{OH})$ attack in position 4, the most requested position in volleyball (Millán-Sánchez et al., 2017), but also because each team as two $\mathrm{OH}$ playing, one near the setter and another away from the setter; this allows comparing the specificity within the role of $\mathrm{OH}$. While we acknowledge that the opposite player is very relevant in many critical scenarios, there is only one opposite in the court at any given moment, and so no within-role comparisons are possible. Ethical approval for the study was given by the Ethics Committee at the Centre of Research, Education, Innovation, and Intervention in Sport of the University of Porto (09 2020 CEFADE).

\section{Measures}

Table 1 presents the study variables. Volleyball is organized in seven co-dependent game complexes (Figure 1) with different game characteristics (Martins et al., 2021): Complex 0 (K0) or serve, Complex I (KI) or side-out, Complex II (KII) or side-out transition, Complex III (KIII) or transition, Complex IV (KIV) or attack coverage, Complex V (KV) or freeball, and Complex VI (KVI) or downball.

One of the tools used for methodological support was Data Volley (2019). It is systematically used in

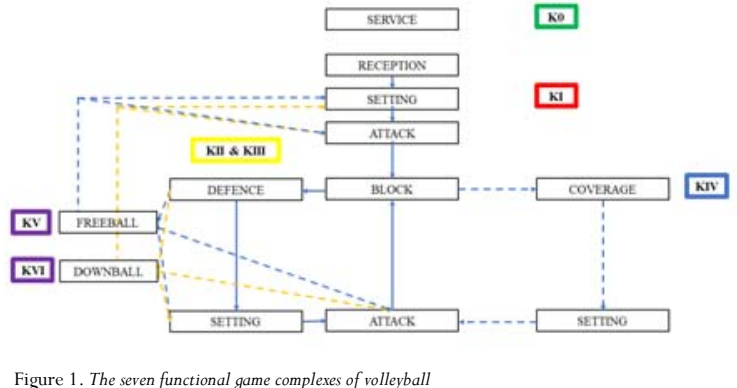

scientific articles in this area with very high interobserver reliability values $(0.82-1)$ being reported in the literature (Costa, Mesquita, Greco, Ferreira, \& Moraes, 2011; Drikos, Ntzoufras, \& Apostolidis, 2019; João \& Pires, 2015; Lima, Palao, Moreira, \& Clemente, 2019; Stamm, Stamm, Torilo, Thomson, \& Jairus, 2016). Thus, Data Volley is now one of the most used tools and addressed in game analysis studies in volleyball. Two variables were considered for Complex 0 . The first was type of serve $(\mathrm{S})$, which had three categories (Martins et al., 2021): (i) power jump serve (PJS; with displacement and explosive jump and with ball rotation), (ii) standing serve (STS; no jump - serve in support), and (iii) jumping-float serve (JFLTS; no ball rotation and uniform trajectory). The second variable was serve efficacy (SE), which had five categories (DataVolley, 2019): (i) perfect - direct point ace (SE\#), (ii) positive - one cannot see combined, only non-ideal setting conditions, usually only with the possibility of an attack (SE+), (iii) exclamatory - serve bulk but recovered (SE!), (iv) negative - the opponent receives the ball \# and can attack in any way (SE-), and (v) error - point to opposite ( $\mathrm{SE}=$; net ball, out, foot foul).

For game complexes I to VI, several variables were analyzed: (1) Setting conditions, with four categories (Hurst et al., 2016): (i) all attack options available (SCA), (ii) quick game, but no combined moves available (SCB), (iii) only attackers from the ends or background court are available (SCC), and (iv) setting could not occur (SCNO); (2) Function of the attack player, with three categories (Millán-Sánchez et al., 2017): (i) outside hitter near setter $(\mathrm{OHN})$, (ii) outside hitter away from setter (OHA), and (iii) attack of $\mathrm{OH}$ could not occur (FNCNO); (3) Attack zone/Combination (AZ/Comb), with five categories (Data Volley, 2019): (i) quick tempo in Z4 (CombX4), (ii) high tempo in Z4 (CombV4), (iii) quick tempo in Z2 (CombX2), (iv) high tempo in Z2 (CombV2), and (v) did not occur (CombNO); (4) Action preceding the attack $(\mathrm{pa})$, with three categories: (i) receiving or defending (Awpa), (ii) no prior action - 
without receiving or defending (Anpa), and (iii) did not occur (paNO); (5) Type of attack (TpA) had five categories (DataVolley, 2019): (i) strong attack (TpSA), (ii) directed attack (TpDA - major control of the attacker), (iii) tip (TpTip), (iv) exploration of the block (TpExpB purposeful attack against the opposing block, making the ball reflect out of the court: from the side or the long of the court), and (v) did not occur (TpNO); (6) Effect of previous attacks (pAE/pTE) had six categories: no error (AaNOE), one previous error by the same attacker (1psAE), two previous errors by the same attacker (2psAE), one previous team error (1pTE), two previous team errors ( $2 \mathrm{pTE})$ and loss of three consecutive points (Aa3PC); (7) Distance of the attacker to the net (An) had three categories: (i) close to the net, from the net until 2.5m (ACn), (ii) away from the net, from $2.5 \mathrm{~m}$ to end of court (AAn), and (iii) did not occur (DANNO); (8) Attack efficacy (AE) had seven categories (Data Volley, 2019): perfect (AE\#), positive $(\mathrm{AE}+)$, exclamatory $(\mathrm{AE} !)$, negative (AE-), poor (AE/ ), error $(\mathrm{AE}=)$, and attack efficacy did not occur (AENO); (9) Block opposition (BOp) had five categories from Data Volley (2019): (i) no block (B0 - without blockers), (ii) simple block (B1 - only one blocker), (iii) double block (B2 - two blockers), (iv) triple block (B3 - three blockers), and (v) block opposition did not occur (BOpNO).

\begin{tabular}{|c|c|c|c|}
\hline Variables & Category & Description & Complex \\
\hline \multicolumn{4}{|c|}{ Game actions } \\
\hline Type of serve (S) & $\begin{array}{l}\text { Power jump serve (PJS) } \\
\text { Standing serve (STS) }\end{array}$ & Jump-float serve (JFLTS) & K0 \\
\hline Serve efficacy (SE) & $\begin{array}{l}\text { \#: Perfect (SE\#) } \\
\text { +: Positive (SE+) } \\
\text { !: Exclamatory (SE!) }\end{array}$ & $\begin{array}{l}-: \text { Negative (SE-) } \\
=\text { : Error }(\mathrm{SE}=)\end{array}$ & K0 \\
\hline Setting Conditions (SC) & $\begin{array}{l}\mathrm{A}(\mathrm{SCA}) \\
\mathrm{B}(\mathrm{SCB})\end{array}$ & $\begin{array}{l}\mathrm{C}(\mathrm{SCC}) \\
\text { NO: did not occur setting } \\
\text { (SCNO) }\end{array}$ & $\mathrm{KI}$ to $\mathrm{KVI}$ \\
\hline $\begin{array}{l}\text { Function of the attack } \\
\text { player (FNC) }\end{array}$ & $\begin{array}{l}\text { Outside hitter near setter } \\
(\mathrm{OHN}) \\
\text { Outside hitter away setter } \\
(\mathrm{OHA})\end{array}$ & $\begin{array}{l}\text { NO: did not occur attack of } \\
\text { OH (FNCNO) }\end{array}$ & $\mathrm{KI}$ to $\mathrm{KVI}$ \\
\hline $\begin{array}{l}\text { Attack } \\
\text { Zone/Combination } \\
\text { (AZ/Comb) }\end{array}$ & $\begin{array}{l}\mathrm{X} 4(\mathrm{CombX} 4) \mathrm{V} 4 \\
\text { (CombV4)X2 (CombX2) }\end{array}$ & $\begin{array}{l}\text { V2 (CombV2)Did not occur } \\
\text { combination (CombNO) }\end{array}$ & $\mathrm{KI}$ to $\mathrm{KVI}$ \\
\hline $\begin{array}{l}\text { Action preceding the } \\
\text { attack (pa) }\end{array}$ & $\begin{array}{l}\text { With previous action } \\
\text { (Awpa) } \\
\text { No prior action (Anpa) }\end{array}$ & Did not occur (paNO) & KI to KVI \\
\hline Type of attack (TpA) & $\begin{array}{l}\text { Strong attack (TpSA) } \\
\text { Directed attack (TpDA) } \\
\text { Tip (TpATip) }\end{array}$ & $\begin{array}{l}\text { Exploration of the block } \\
\text { (TpAExpB) } \\
\text { Did not occur (TpNO) }\end{array}$ & $\mathrm{KI}$ to $\mathrm{KVI}$ \\
\hline $\begin{array}{l}\text { Effect of previous attacks } \\
\text { (pAE/pTE) }\end{array}$ & $\begin{array}{l}\text { No error (AaNOE) } \\
1 \text { previous same attacker } \\
\text { error (1psAE) } \\
2 \text { previous errors of the } \\
\text { same attacker ( } 2 \mathrm{psAE})\end{array}$ & $\begin{array}{l}1 \text { previous team error ( } 1 \mathrm{pTE}) \\
2 \text { previous team errors }(2 \mathrm{pTE}) \\
\text { Loss of } 3 \text { consecutive points } \\
\text { (Aa3PC) }\end{array}$ & KI to KVI \\
\hline $\begin{array}{l}\text { Distance of the attacker } \\
\text { to the net }(\mathrm{An})\end{array}$ & $\begin{array}{l}\text { Away from the net }(\mathrm{AAn}) \\
\text { Close to the net }(\mathrm{ACn})\end{array}$ & Did not occur (DANNO) & $\mathrm{KI}$ to $\mathrm{KVI}$ \\
\hline Attack Efficacy (AE) & $\begin{array}{l}\text { \#: Perfect (AE\#) } \\
\text { +: Positive (AE+) } \\
\text { !: Exclamatory (AE!) }\end{array}$ & $\begin{array}{l}-: \text { Negative }(\mathrm{AE}-) \\
\text { /: Poor }(\mathrm{AE} /) \\
=: \text { Error }(\mathrm{AE}=) \\
\text { Did not occur efficacy } \\
(\mathrm{AENO})\end{array}$ & $\mathrm{KI}$ to $\mathrm{KVI}$ \\
\hline Block opposition (BOp) & $\begin{array}{l}\text { No Blockers (B0) } \\
\text { Simple block (B1) } \\
\text { Double block (B2) }\end{array}$ & $\begin{array}{l}\text { Triple block (B3) } \\
\text { Did not occur (BOpNO) }\end{array}$ & KII to KVI \\
\hline
\end{tabular}

\section{Design and Procedures}

First, a spreadsheet was built in Microsoft Excel 2018 for Windows (Microsoft Office 365 ProPlus, EUA) including «Macros» buttons to catalog the necessary codes into the appropriate cells. Three of the authors were then trained to use this tool. Two reliability tests were performed during this training period (the first after four months of testing the instrument; the second after five months) to ensure consistency when applying the criteria, and to adjust the variables and categories where needed. During the months of training, weekly online sessions were held to respond to questions and to discuss arising issues. The first inter-reliability test was performed in an exploratory study of a play-off in the 2018/2019 Portuguese national championship (Martins et al., 2021). For all variables, Kappa values above 0.75 were obtained (ranging from .774 to .997). However, due to the size of the instrument, we reduced some variables to improve robustness and focus.

A second inter-observer reliability test was performed using two high-level women's matches (one match from the quarterfinals of the 2018/2019 CEV Challenge Cup and another from the 2018/2019 final of the Brazilian Women's Superliga, for a total of eight sets), with a total of 134 plays. All the variables had kappa values above 0.75 (Tabachnick \& Fidell, 2007). The 11 variables included in the final version are presented in Table 1. A final test of inter-observer reliability was performed on 159 plays of two matches from the 2018/2019 final of the Brazilian Men's Superliga, totaling nine sets. In this final test, all variables had kappa values above 0.75 , which is considered acceptable (Tabachnick \& Fidell, 2007). After this validation process, the tool was used with the present study sample to analyze videos of the matches, recorded in high definition (1080p) from the end of the court (with the camera positions slightly higher than the net).

\section{Statistical Analysis}

After data collection, inter-and intra-observer reliability were assessed using $10 \%$ of the total sample - 65 plays - (Fleiss, Levin, \& Paik, 2013). Kappa values for inter-observer reliability were greater than the threshold of 0.75 proposed by Tabachnick and Fidell (2007), ranging from .980 to .999. Subsequently, data were analyzed using SPSS for Windows (version 26, $\mathrm{IBM}^{\circledR}$, USA). This included a descriptive analysis to identify potential errors, followed by the production of contingency tables to investigate data quality. In next step, SNA was used to analyse inter-team variability in 
critical game scenarios. In SNA, interaction networks analyse the level of connection and specificity in different game phases (Wäsche et al., 2017). SNA also captures networks of relationships, visually converted into nodes interconnected by edges (Borgatti, 2005). Edges are defined in units (number of connections), signifying heavier edges corresponding a greater number of connections between two nodes (Laporta, Afonso, \& Mesquita, 2018). While the most widely used measure in SNA is Degree Centrality (Gama et al., 2014; Laporta et al., 2021; Mclean, Salmon, Gorman, Stevens, \& Solomon, 2018), Eigenvector Centrality has the advantage of also weighting direct connections based on their indirect connections (Bonacich, 2007).

$\mathrm{Gephi}^{\odot}$ 0.9.2 software was used to create networks and analyse the connections and their weights using Eigenvector Centrality. The variables (game actions) were allocated into each game complex in sequence centered on the game events, with every game action recognized as a node. Direct and indirect connections between the nodes were calculated, using Gephi, and thus the weight of the variables and their influence in the game were calculated at critical game scenarios. The node sizes were engineered a value of 100 and 300, to offer good quality graphic variation. These values are an arbitrary and relative measure. Edges are described in units (number of connections), meaning thicker edges signify a greater number of links between two nodes (Laporta et al., 2018). For example, attack zone appears simultaneously with type of attack, so categories of the attack zone determine link with the attack type.Though, attack zone is headed by setting conditions and followed by block opposition, thus it results in new direct links to these two variables. Subsequently, Eigenvector Centrality offers a method for calculating the weight of indirect connections, such as attack zone and reception or defence. In sum, SNA can be used to demonstrate the complex dynamics of the game actions in critical game scenarios, within each game phase, and to highlight the decisive role of each node (Martins et al., 2021).

\section{Results}

A network for each team was created using Eigenvector Centrality to provide a map of interactions (Figure 2-4 and Table 2). In each network, complexes were defined by a specific color: K0 (blue), KI (red), KII (green), KIII (purple), KIV (yellow), KV (grey), and KVI (orange). In total, we counted 632 nodes (Russia: 98; United States: 107; Poland: 108; Iran: 102; France:
96; and Brazil: 121) and 3,507 edges (Russia: 714; United States: 495; Poland: 500; Iran: 671; France: 577; and Brazil: 550).

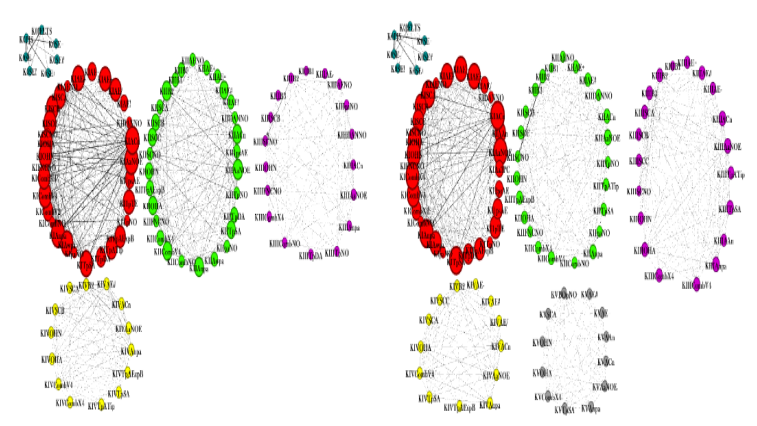

Figure 2. Eigenvector Centrality Networks of Russia (left) and USA (right). Terminology: On each node, the codes are represented by the name of the complex, followed by the variable and its category. For example, KIISSA indicates that the action occurred in complex II, corresponding to the setting conditions, in this case meaning ideal setting conditions, with four attack points. The codes for the different variables are: $S$ - type of serve; $S E$ - serve efficacy; $S C$ - setting conditions; $F N C$ - function of the attack player; Comb - attack zone/ combinations; TPA - type of attack; $A E$ - attack efficacy; $p a$ - action preceding the attack; $P A E / P T E$ - effect of previous attacks; $A n$ - distance of the attacker to the net; and $B O P$ - block opposition.

Russia typically used power-jump serves in K0, and mostly with control (both JFLTS and PJS). In KI, this team worked in ideal setting conditions. In this complex, Russia frequently requested the opposite (OPP) and $\mathrm{OH}$, with a preference for the strong attack followed by the attack exploring the opposing block. After successive errors (from a player or team), Russia tended to seek a strong attack by the $\mathrm{OH}$, regardless of the type of error. In KII, the block was mostly performed by two players. Setting was typically performed in SCB, with a high ball game in zones 4 and 2, requesting the $\mathrm{OH}$ and $\mathrm{OPP}$, and favoring the strong attack. Of the remaining complexes, this team spent more time in KIV and always had ideal setting conditions, with the players at the extremities (mainly the $\mathrm{OH}$ ) being the most requested, using a strong attack and exploration of the opposing block.

The United States mostly used the power-jump serve and did so with high efficacy. Like Russia, the USA had ideal setting conditions. However, unlike Russia, they tended to favor a quick game with the middle-blocker (MB). Under non-ideal setting conditions, the players at the extremities were the most requested, especially the $\mathrm{OH}$, using a strong and exploited attack in the block. In KII and KIII, the trends differed. Specifically, the USA had a slower game (due to setting conditions), with the high ball at the extremities, and the use of the strong attack by the $\mathrm{OH}$. In KIV, the setting conditions alternated between ideal and non-ideal. However, the $\mathrm{OH}$ was always requested, with a tendency for either the strong attack or exploration of the block. The $\mathrm{OH}$ was also requested in freeball to seek a strong attack. 


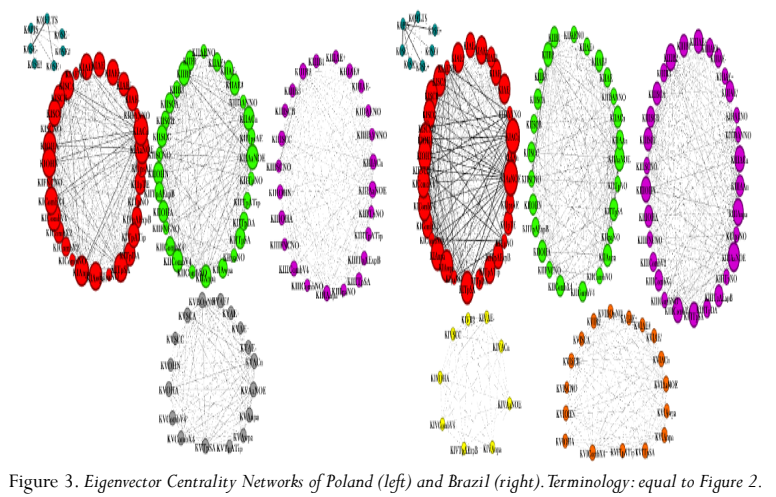

Unlike the other teams, Poland had a high serve efficacy using mostly the jump-float serve. In KI, nonideal setting conditions were prevalent. In these conditions, the extremities were requested with quick ball and high tempo. The prevailing type of attack was the strong attack alternating with the directed and tip attacks (notably distinct from the other teams). However, under ideal setting conditions, Poland searched for the MB. In KII, the block opposition was performed with two players and the setting conditions were mainly non-ideal, with a tendency for the attacker of Z4 to use high ball and a strong or exploited attack in the block. In KIII, this team used the OPP as a resource in alternation with the $\mathrm{OH}$ in a strong attack. Also, this team did not have any cover work throughout the competition. In $\mathrm{KV}$, like all teams, the $\mathrm{OH}$ was the most requested player with ideal setting conditions, typically making a strong attack at the extremities, often against a simple block.

For Brazil, the power-jump serve was the most central throughout $\mathrm{K} 0$, with the second-best efficacy in this type of game action. In KI, this team had good setting conditions, like the USA. However, their centralities in the attack varied between the OPP and the $\mathrm{OH}$, with a large fixation and some volume with the MB. Unlike other teams, Brazil frequently searched for the MB in SCB settings conditions. With non-ideal conditions, they often sought for the security player, $\mathrm{OH}$. In all cases, the strong attack was the most sought after in the final part of the set. These strong attacks, mostly performed by the $\mathrm{OH}$, were of high efficacy. In KII, Brazil transitioned to a double block under non-ideal setting conditions (SCB and SCC). In this complex, there was a tendency for OPP to operate in a network of three attackers, and the $\mathrm{OH}$ to operate in a network of two attackers. The strong attack was once again preferred, with continuing good efficacy. In KIII, the $\mathrm{OH}$ was the least sought-after player because of the ideal setting conditions, and most likely due to the characteristics of the team's attackers. MB and OPP were used frequently in this complex in a strong attack. There was a low occurrence of KIV, and this typically involved the $\mathrm{OH}$ using a strong attack.

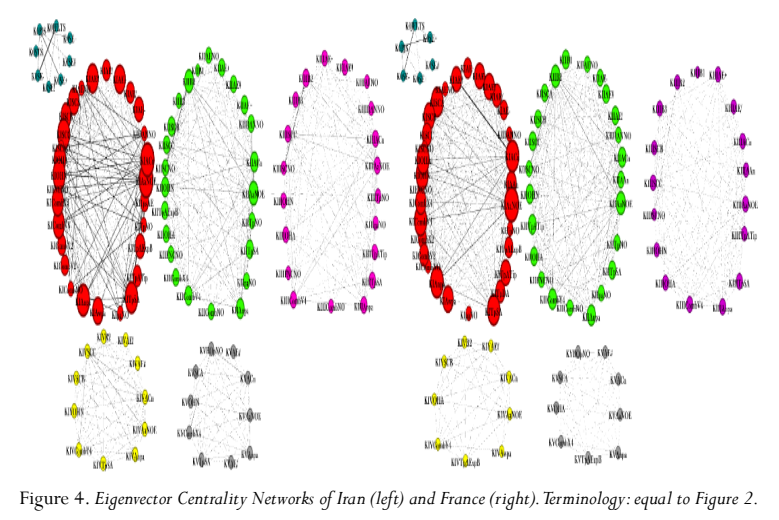

Iran used all the three major types of serve (JFLTS, PJS, STS) in K0, although JFLTS was the most common. Iran's serve efficacy was higher than most other teams. In KI, Iran had more SCC conditions, and the players at the extremities played a stronger game, using high ball almost always with a strong attack. In KII, because of playing a game with SCA via the OPP, and a game with $\mathrm{SCB}$ and $\mathrm{SCC}$ via the $\mathrm{OH}$, this $\mathrm{OH}$ behavior had additional control characteristics and volume. In KIII, the game features persisted from KII. In the remaining complexes (in KIV and KV) the setting conditions were ideal, with a tendency to look for the $\mathrm{OH}$ through a strong attack and with a quick game.

Like Iran, France only played in the group stage. This team had a low serve efficacy in the jump-float and power serve, meaning their opponents were able to play comfortably. In side-out, the setting conditions were playable (A and B), which made the quick play possible. As such, a strong attack on the extremities was the most sought after. In KII, non-ideal setting conditions were common. The MB was typically used in SCB conditions, while the OPP in the extremities was used in SCC conditions. The strong attack, and a game with high ball, were the most common, with the aim of giving volume and playing in the opponent's error. The remaining complexes (KIII and KV) had low occurrence and mostly involved $\mathrm{OH}$ as an attacker with a high ball game and strong attack.

\section{Discussion}

In sports, the concept of inter-team variability in game patterns acknowledges that distinct teams may approach the game differently. Past match analysis-based research on inter-team variability has mostly focused 
Eigenvector Centrality values for each team comple

\begin{tabular}{|c|c|c|c|c|c|c|c|}
\hline Complex & Variables & Russia & United States & Poland & Brazil & Iran & France \\
\hline \multirow[t]{2}{*}{ K0 } & Type of serve (S) & JFLTS (0.006); PJS (0.006) & JFLTS (0.006); PJS (0.006) & JFLTS (0.005); PJS (0.005) & JFLTS (0.004); PJS (0.005) & $\begin{array}{l}\text { JFLTS }(0.006) ; \text { PJS } \\
(0.007) \text {; STS }(0.001)\end{array}$ & JFLTS (0.003); PJS (0.004) \\
\hline & Serve efficacy (SE) & $\begin{array}{l}\text { SE\# (0.003); SE+ (0.003); SE! } \\
(0.003) \text {; SE- }(0.003) ; \mathrm{SE}= \\
(0.003)\end{array}$ & $\begin{array}{l}\text { SE\# }(0.003) ; \mathrm{SE}+(0.003) ; \\
\text { SE! }(0.003) ; \mathrm{SE}-(0.003) ; \\
\mathrm{SE}=(0.003)\end{array}$ & $\begin{array}{l}\text { SE\# (0.003); SE+ (0.003); SE! } \\
(0.003) ; \text { SE- }(0.003) ; \mathrm{SE}=(0.003)\end{array}$ & $\begin{array}{l}\text { SE\# (0.001); SE }+(0.003) ; \\
\text { SE! (0.003); SE- }(0.003) ; \text { SE }= \\
(0.003)\end{array}$ & $\begin{aligned} & \text { SE\# }(0.002) ; \mathrm{SE}+ \\
&=(0.004) ; \mathrm{SE} !(0.004) ; \mathrm{SE}- \\
&(0.005) ; \mathrm{SE}=(0.004)\end{aligned}$ & $\begin{array}{l}\text { SE\# (0.001); SE+ }(0.003) ; \\
\text { SE! }(0.004) ; \text { SE- }(0.003) ; \\
\text { SE }=(0.003)\end{array}$ \\
\hline \multirow[t]{8}{*}{$\mathrm{KI}$} & Setting conditions (SC) & $\begin{array}{l}\text { SCA }(0.762) ; \text { SCB }(0.798) \\
\text { SCC }(0.844) ; \text { SCNO }(0.112)\end{array}$ & $\begin{array}{l}\text { SCA }(0.918) ; \operatorname{SCB}(0.722) ; \\
\text { SCC }(0.691) ; \operatorname{SCNO}(0.112)\end{array}$ & $\begin{array}{l}\text { SCA (0.893); SCB (0.692); SCC } \\
(0.810) ; \text { SCNO }(0.104)\end{array}$ & $\begin{array}{l}\text { SCA (0.798); SCB }(0.749) ; \\
\text { SCC (0.746); SCNO }(0.111)\end{array}$ & $\begin{array}{l}\text { SCA }(0.656) ; \text { SCB } \\
(0.596) ; \text { SCC }(0.814) ; \\
\text { SCNO }(0.144)\end{array}$ & $\begin{array}{l}\text { SCA }(0.779) ; \operatorname{SCB}(0.671) ; \\
\text { SCC }(0.502) ; \operatorname{SCNO}(0.128)\end{array}$ \\
\hline & $\begin{array}{l}\text { Function of the attack } \\
\text { player (FNC) }\end{array}$ & $\begin{array}{l}\text { OHN (0.900); OHA ( } 0.883) \text {; } \\
\text { FNCNO }(0.112)\end{array}$ & $\begin{array}{l}\mathrm{OHN}(0.940) ; \mathrm{OHA} \\
(0.930) ; \mathrm{FNCNO}(0.112)\end{array}$ & $\begin{array}{l}\text { OHN }(0.953) \text {; OHA }(0.855) ; \\
\text { FNCNO }(0.104)\end{array}$ & $\begin{array}{l}\text { OHN }(0.880) ; \text { OHA }(0.911) ; \\
\text { FNCNO }(0.111)\end{array}$ & $\begin{array}{l}\text {; OHN (0.835); OHA } \\
(0.758) ; \text { FNCNO }(0.144)\end{array}$ & $\begin{array}{l}\text { OHN }(0.784) ; \text { OHA } \\
(0.795) ; \text { FNCNO }(0.128)\end{array}$ \\
\hline & $\begin{array}{l}\text { Attack } \\
\text { Zone/Combination } \\
(\mathrm{Cmb})\end{array}$ & $\begin{array}{l}\text { CombX4 (0.781); CombV4 } \\
(0.856) ; \text { CombV2 (0.591); } \\
\text { CombNO (0.112) }\end{array}$ & $\begin{array}{l}\text { CombX4 (0.316); CombV4 } \\
\text { (0.853); CombX2 (0.532); } \\
\text { CombNO (0.112) }\end{array}$ & $\begin{array}{l}\text { CombX4 (0.850); CombV4 } \\
(0.897) ; \text { CombX2 (0.578); } \\
\text { CombV2 (0.439); CombNO } \\
(0.104)\end{array}$ & $\begin{array}{l}\text { CombX4 (0.806); CombV4 } \\
(0.848) ; \text { CombX2 (0.620); } \\
\text { CombNO (0.111) }\end{array}$ & $\begin{array}{l}\text { CombX4 (0.738); } \\
\text { CombV4 (0.737); } \\
\text { CombX2 (0.409); } \\
\text { CombV2 (0.381); } \\
\text { CombNO (0.144) }\end{array}$ & $\begin{array}{l}\text { CombX4 (0.613); CombV4 } \\
\text { (0.819); CombX2 (0.374); } \\
\text { CombV2 (0.478); CombNO } \\
(0.128)\end{array}$ \\
\hline & $\begin{array}{l}\text { Action preceding the } \\
\text { attack (pa) }\end{array}$ & $\begin{array}{l}\text { Anpa (0.952); Awpa (0.829); } \\
\text { pNO (0.112) }\end{array}$ & $\begin{array}{l}\text { Anpa }(0.972) \text {; Awpa }(0.760) ; \\
\text { paNO }(0.112)\end{array}$ & $\begin{array}{l}\text {; Anpa (0.953); Awpa (0.857); } \\
\text { pNO }(0.104)\end{array}$ & $\begin{array}{l}\text { Anpa (0.875); Awpa (0.856); } \\
\text { paNO (0.111) }\end{array}$ & $\begin{array}{l}\text { Anpa (0.876); Awpa } \\
(0.677) ; \text { paNO }(0.144)\end{array}$ & $\begin{array}{l}\text { Anpa }(0.864) ; \text { Awpa }(0.647) ; \\
\text { paNO }(0.128)\end{array}$ \\
\hline & Type of attack (TpA) & $\begin{array}{l}\text { TpSA }(0.889) ; \text { TpDA }(0.546) ; \\
\text { TpATip }(0.708) ; \text { TpAExpB } \\
(0.676) ; \text { TpNO }(0.112)\end{array}$ & $\begin{array}{l}\text { TpSA (0.967);TpDA } \\
(0.577) ; \mathrm{TpAExpB}(0.651) ; \\
\text { TpNO (0.112) }\end{array}$ & $\begin{array}{l}\text { TpSA }(0.894) ; \mathrm{TpDA}(0.658) ; \\
\text { TpAExpB }(0.568) ; \mathrm{T} \text { TATip } \\
(0.692) ; \mathrm{TpNO}(0.104)\end{array}$ & $\begin{array}{l}\text { TpSA (0.881);TpDA (0.361); } \\
\text { TpAExpB (0.611); TpATip } \\
(0.661) ; \operatorname{TpNO}(0.111)\end{array}$ & $\begin{array}{l}\text { TpSA (0.857); TpAExpB } \\
(0.565) ; \text { TpATip }(0.434) ; \\
\text { TpNO (0.144) }\end{array}$ & $\begin{array}{l}\text { TpSA (0.857); TpDA } \\
\text { (0.481);TpAExpB }(0.400) ; \\
\text { TpATip (0.615);TpNO } \\
(0.128)\end{array}$ \\
\hline & $\begin{array}{l}\text { Effect of previous } \\
\text { attacks (pAE) }\end{array}$ & $\begin{array}{l}\text { AaNOE (0.982); } 1 \text { psAE } \\
(0.501) ; 1 \text { pTE }(0.792)\end{array}$ & $\begin{array}{l}\text { AaNOE (0.952); 1 1psAE } \\
(0.577) ; 2 \text { psAE (0.384); }\end{array}$ & $\begin{array}{l}\text { AaNOE (0.987); 1psAE (0.512); } \\
\text { 1pTE (0.639); }\end{array}$ & $\begin{array}{l}\text { AaNOE (0.99); 1psAE } \\
(0.396) ; 1 \text { pTE }(0.505) ; 2 \text { psAE } \\
(0.384) ;\end{array}$ & $\begin{array}{l}\text { AaNOE (0.99); } 1 \mathrm{psAE} \\
\mathrm{E}(0.398) ; 1 \mathrm{pTE}(0.505) ; \\
2 \mathrm{psAE}(0.384) ;\end{array}$ & $\operatorname{AaNOE}(0.99)$ \\
\hline & $\begin{array}{l}\text { Distance of the attacker } \\
\text { to the net (An) }\end{array}$ & r ACn (0.99); DANNO (0.112) & $\begin{array}{l}\text { ACn (0.99); AAn (0.671); } \\
\text { DANNO (0.112) }\end{array}$ & ACn (0.99); DANNO (0.104) & $\begin{array}{l}\text { ACn (0.973); DANNO } \\
(0.111)\end{array}$ & $\begin{array}{l}\text { ACn (0.947); DANNO } \\
(0.144)\end{array}$ & $\begin{array}{l}\text { ACn }(0.876) ; \operatorname{AAn}(0.587) ; \\
\text { DANNO (0.128) }\end{array}$ \\
\hline & $\overline{\text { Attack efficacy (AE) }}$ & $\begin{array}{l}\mathrm{AE \#}(0.830) ; \mathrm{AE}+(0.794) ; \\
\mathrm{AE} /(0.723) ; \mathrm{AE!}(0.379) ; \mathrm{AE}= \\
(0.481) ; \mathrm{AENO}(0.112)\end{array}$ & $\begin{aligned} & \mathrm{AE \#}(0.775) ; \mathrm{AE}+(0.845) ; \\
&=\mathrm{AE} /(0.385) ; \mathrm{AE}=(0.812) ; \\
& \\
& \text { AENO }(0.112)\end{aligned}$ & $\begin{array}{l}\text { AE\# (0.760); } \mathrm{AE}+(0.750) ; \mathrm{AE} / \\
(0.647) ; \mathrm{AE}-(0.688) ; \mathrm{AE}= \\
(0.679) ; \mathrm{AENO}(0.104)\end{array}$ & $\begin{array}{l}\mathrm{AE \#}(0.755) ; \mathrm{AE}+(0.680) ; \\
\mathrm{AE} /(0.610) ; \mathrm{AE!}(0.374) ; \\
\mathrm{AE}-(0.750) ; \mathrm{AE}=(0.559) ; \\
\mathrm{AENO}(0.111)\end{array}$ & $\begin{array}{l}\text { AE\# (0.756); } \mathrm{AE}+ \\
(0.718) ; \mathrm{AE} /(0.422) ; \mathrm{AE!} \\
(0.409) ; \mathrm{AE}-(0.561) ; \\
\mathrm{AENO}(0.144)\end{array}$ & $\begin{array}{l}\mathrm{AE \#}(0.603) ; \mathrm{AE}+(0.617) ; \\
\mathrm{AE} /(0.507) ; \mathrm{AE!}(0.639) ; \\
\mathrm{AE}-(0.342) ; \mathrm{AE}=(0.389) ; \\
\mathrm{AENO}(0.128)\end{array}$ \\
\hline \multirow[t]{9}{*}{ KII } & $\begin{array}{l}\text { Block opposition } \\
\text { (BOp) }\end{array}$ & $\begin{array}{l}\text { B0 (0.289); B1 }(0.262) ; \text { B2 } \\
(0.549)\end{array}$ & $\begin{array}{l}\text { B1 }(0.010) ; \text { B2 }(0.222) ; B 3 \\
(0.213)\end{array}$ & B1 (0.471); B2 (0.680); B3 (0.304) & $\begin{array}{l}\text { B1 (0.398); B2 (0.518); B3 } \\
(0.140)\end{array}$ & $\begin{array}{l}\text { B1 }(0.018) ; \text { B2 }(0.489) ; \text { B3 } \\
(0.154)\end{array}$ & BB1 (0.330); B2 (0.477) \\
\hline & Setting conditions (SC) & $\begin{array}{l}\text { SCA }(0.261) ; \operatorname{SCB}(0.398) ; \\
\text { SCC }(0.453) ; \operatorname{SCNO}(0.194)\end{array}$ & $\begin{array}{l}\text { SCB }(0.153) ; \operatorname{SCC}(0.212) ; \\
\text { SCNO }(0.119)\end{array}$ & $\begin{array}{l}\text { SCA }(0.492) ; \operatorname{SCB}(0.371) ; \operatorname{SCC} \\
(0.571) ; \operatorname{SCNO}(0.206)\end{array}$ & $\begin{array}{l}\text { SCA }(0.368) ; \operatorname{SCB}(0.296) ; \\
\text { SCC }(0.361) ; \operatorname{SCNO}(0.200)\end{array}$ & $\begin{array}{l}\text { SCB }(0.333) ; \mathrm{SCC} \\
(0.271) ; \operatorname{SCNO}(0.209)\end{array}$ & $\begin{array}{l}\text { SCA }(0.260) ; \operatorname{SCB}(0.259) ; \\
\text { SCC }(0.320) ; \operatorname{SCNO}(0.193)\end{array}$ \\
\hline & $\begin{array}{l}\text { Function of the attack } \\
\text { player (FNC) }\end{array}$ & $\begin{array}{l}\text { OHN }(0.395) ; \text { OHA }(0.492) \\
\text { FNCNO }(0.158)\end{array}$ & $\begin{array}{l}\mathrm{OHN}(0.227) ; \mathrm{OHA} \\
(0.183) ; \mathrm{FNCNO}(0.101)\end{array}$ & $\begin{array}{l}\text { OHN (0.227); OHA }(0.183) ; \\
\text { FNCNO (0.101) }\end{array}$ & $\begin{array}{l}\text { OHN }(0.380) \text {; OHA }(0.425) \text {; } \\
\text { FNCNO }(0.200)\end{array}$ & $\begin{array}{l}\text {; OHN (0.353); OHA } \\
(0.249) ; \text { FNCNO }(0.207)\end{array}$ & $\begin{array}{l}\text { OHN }(0.340) ; \text { OHA } \\
(0.303) ; \text { FNCNO }(0.193)\end{array}$ \\
\hline & $\begin{array}{l}\text { Attack } \\
\text { Zone/Combination } \\
(\mathrm{Cmb})\end{array}$ & $\begin{array}{l}\text { CombX4 (0.326); CombV4 } \\
(0.514) ; \text { CombNO (0.158) }\end{array}$ & $\begin{array}{l}\text { CombX4 (0.165); CombV4 } \\
(0.212) ; \text { CombNO }(0.101)\end{array}$ & $\begin{array}{l}\text { CombX4 (0.442); CombV4 } \\
(0.623) ; \text { CombNO }(0.160)\end{array}$ & $\begin{array}{l}\text { CombX4 (0.387); CombV4 } \\
(0.361) ; \text { CombNO }(0.200)\end{array}$ & $\begin{array}{l}\text { CombX4 }(0.242) \\
\text { CombV4 }(0.335) \\
\text { CombNO }(0.207)\end{array}$ & $\begin{array}{l}\text { CombV4 (0.401); CombNO } \\
(0.193)\end{array}$ \\
\hline & $\begin{array}{l}\text { Action preceding the } \\
\text { attack (pa) }\end{array}$ & $\begin{array}{l}\text { Anpa }(0.534) ; \text { Awpa }(0.274) ; \\
\text { paNO }(0.158)\end{array}$ & Anpa (0.253); paNO (0.101) & $\begin{array}{l}\text { Anpa }(0.605) ; \text { Awpa }(0.453) ; \\
\text { paNO }(0.160)\end{array}$ & Anpa (0.449); paNO (0.200) & $\begin{array}{l}\text { Anpa (0.372); paNO } \\
(0.207)\end{array}$ & Anpa (0.401); paNO (0.193) \\
\hline & Type of attack (TpA) & $\begin{array}{l}\text { TpSA }(0.458) ; \mathrm{TpDA}(0.319) ; \\
\mathrm{TpAExpB}(0.334) ; \mathrm{T} \mathrm{NO} \\
(0.158)\end{array}$ & $\begin{array}{l}\text { TpSA (0.163);TpDA } \\
(0.319) ; \text { TpAExpB }(0.216) ; \\
\text { TpATip }(0.153) ; \text { TpNO } \\
(0.101)\end{array}$ & $\begin{array}{l}\text { TpSA }(0.540) ; \text { TpDA }(0.389) ; \\
\text { TpAExpB }(0.462) ; \text { TpATip } \\
(0.305) ; \operatorname{TpNO}(0.160)\end{array}$ & $\begin{array}{l}\text { TpSA (0.429); TpAExpB } \\
(0.320) ; \text { TpNO }(0.200)\end{array}$ & $\begin{array}{l}\text { TpSA (0.315); TpAExpB } \\
(0.268) ; \text { TPNO }(0.194)\end{array}$ & $\begin{array}{l}\text { TpSA (0.301);TpATip } \\
(0.362) ; T \text { TpO }(0.193)\end{array}$ \\
\hline & $\begin{array}{l}\text { Effect of previous } \\
\text { attacks (pAE) }\end{array}$ & $\begin{array}{l}\text { AaNOE (0.597); 1 psAE } \\
(0.246)\end{array}$ & AaNOE (0.314) & 1psAE (0.293); AaNOE (0.708) & AaNOE $(0.554)$ & AaNOE $(0.532)$ & $\mathrm{AaNOE}(0.501)$ \\
\hline & $\begin{array}{l}\text { Distance of the attacker } \\
\text { to the net }(\mathrm{An})\end{array}$ & $\mathrm{ACn}(0.536) ;$ DANNO (0.158) & $\begin{array}{l}\text { ACn }(0.253) ; \text { DANNO } \\
(0.101)\end{array}$ & ACn (0.649); DANNO (0.160) & $\begin{array}{l}\text { ACn }(0.429) ; \text { AAn }(0.320) \text {; } \\
\text { DANNO (0.200) }\end{array}$ & $\begin{array}{l}\text { ACn }(0.372) \text {; DANNO } \\
(0.248)\end{array}$ & $\begin{array}{l}\text { ACn }(0.369) ; \text { DANNO } \\
(0.193)\end{array}$ \\
\hline & $\overline{\text { Attack efficacy (AE) }}$ & $\begin{array}{l}\mathrm{AE \#}(0.464) ; \mathrm{AE}+(0.575) ; \\
\mathrm{AE} /(0.611) ; \mathrm{AE}=(0.483) ; \\
\mathrm{AENO}(0.274)\end{array}$ & $\begin{array}{l}\text { AE\# }(0.216) ; \mathrm{AE}+(0.180) \text {; } \\
\text { AENO }(0.101)\end{array}$ & $\begin{array}{l}\mathrm{AE \#}(0.539) \text {; } \mathrm{AE}+(0.394) \text {; } \mathrm{AE}- \\
(0.453) ; \mathrm{AENO}(0.160)\end{array}$ & $\begin{array}{l}\mathrm{AE \#}(0.413) ; \mathrm{AE}+(0.243) ; \\
\mathrm{AE}=(0.319) ; \mathrm{AENO}(0.200)\end{array}$ & $\begin{array}{l}\mathrm{AE \#}(0.242) ; \mathrm{AE}+ \\
(0.248) ; \mathrm{AE}=(0.296) ; \\
\mathrm{AENO}(0.207)\end{array}$ & $\begin{array}{l}\text { AE\# (0.305); AE- }(0.230) ; \\
\text { AE! }(0.301) ; A E N O(0.193)\end{array}$ \\
\hline \multirow[t]{9}{*}{ KIII } & BOp & $\begin{array}{l}\text { B1 }(0.009) ; \text { B2 }(0.060) ; \mathrm{B} 3 \\
(0.067)\end{array}$ & $\begin{array}{l}\text { B1 }(0.003) ; B 2(0.222) ; B 3 \\
(0.230)\end{array}$ & B1 (0.154); B2 (0.270); B3 (0.150) & $\begin{array}{l}\text { B1 (0.443); B2 (0.619); B3 } \\
(0.282)\end{array}$ & B2 $(0.271)$; B3 $(0.165)$ & $\begin{array}{l}\text { B1 (0.003); B2 (0.126); B3 } \\
(0.168)\end{array}$ \\
\hline & $\overline{\mathrm{SC}}$ & SCB $(0.059) ; \operatorname{SCNO}(0.083)$ & $\begin{array}{l}\text { SCA }(0.219) ; \operatorname{SCB}(0.156) ; \\
\text { SCC }(0.151) ; \operatorname{SCNO}(0.083)\end{array}$ & $\begin{array}{l}\text { SCB }(0.148) ; \operatorname{SCC}(0.237) ; \text { SCNO } \\
(0.118)\end{array}$ & $\begin{array}{l}\text { SCA (0.465); SCB }(0.395) ; \\
\text { SCC }(0.473) ; \operatorname{SCNO}(0.211)\end{array}$ & $\begin{array}{l}\text { SCC }(0.222) ; \text { SCNO } \\
(0.100)\end{array}$ & $\begin{array}{l}\mathrm{SCB}(0.125) ; \operatorname{SCC}(0.175) ; \\
\text { SCNO }(0.027)\end{array}$ \\
\hline & $\overline{\mathrm{FNC}}$ & OHN (0.059); FNCNO & OHA $(0.238) ;$ OHN $(0.168)$ & OHA $(0.202) ;$ OHN $(0.186)$ & OHA $(0.427)$; OHN $(0.580)$; & ; OHN (0.163); OHA & OHN $(0.123)$; OHA $(0.165)$ \\
\hline & $\overline{\mathrm{Cmb}}$ & $\begin{array}{l}(0.060) \\
\text { CombX4 (0.059); CombNO } \\
(0.060)\end{array}$ & $\begin{array}{l}\text { CombX4 (0.219); CombV4 } \\
(0.231) ; \text { CombNO }(0.060)\end{array}$ & $\begin{array}{l}\text { FNCNO (0.96) } \\
\text { CombV4 (0.247); CombNO } \\
(0.096)\end{array}$ & $\begin{array}{l}\text { FNCNO }(0.165) \\
\text { CombV4 (0.558); CombV2 } \\
(0.304) ; \text { CombNO }(0.165)\end{array}$ & $\begin{array}{l}(0.193) ; \mathrm{FNCNO}(0 \\
\text { CombV4 }(0.222) ; \\
\text { CombNO }(0.085)\end{array}$ & CombV4 (0.196) \\
\hline & pa & Anpa $(0.059) ;$ paNO $(0.060)$ & Anpa (0.284) & Anpa (0.247); paNO (0.96) & Anpa (0.637); paNO (0.165) & $\begin{array}{l}\text { Anpa (0.222); paNO } \\
(0.085)\end{array}$ & Anpa $(0.196)$ \\
\hline & TpA & TpDA (0.067); TpNO (0.067) & $\begin{array}{l}\text { TpSA (0.248); TpATip } \\
(0.167)\end{array}$ & $\begin{array}{l}\text { TpSA (0.201); TpATip (0.149); } \\
\text { TpNO (0.96) }\end{array}$ & $\begin{array}{l}\text { TpSA (0.556); TpAExpB } \\
(0.421) ; \text { TpDA (0.299); } \\
\text { TpNO (0.165) }\end{array}$ & $\begin{array}{l}\text { TPSA (0.208); TpATip } \\
(0.161) ; \text { TpNO (0.26) }\end{array}$ & $\begin{array}{l}\text { TPSA (0.186); TpATip } \\
(0.129)\end{array}$ \\
\hline & $\overline{\mathrm{pAE}}$ & AaNOE $(0.109)$ & AaNOE $(0.284)$ & AaNOE $(0.284)$ & AaNOE $(0.737)$ & AaNOE $(0.737)$ & AaNOE $(0.196)$ \\
\hline & $\mathrm{An}$ & ACn (0.059); DANNO (0.067) & ACn (0.272); $\operatorname{AAn}(0.157)$ & $\operatorname{ACn}(0.247) ; \operatorname{DANNO}(0.96)$ & $\begin{array}{l}\text { ACn }(0.600) ; \text { AAn }(0.400) ; \\
\text { DANNO (0.165) }\end{array}$ & $\begin{array}{l}\text { ACn }(0.600) ; \text { DANNO } \\
(0.105)\end{array}$ & $\operatorname{ACn}(0.175) ; \operatorname{AAn}(0.125)$ \\
\hline & $\overline{\mathrm{AE}}$ & AE- $(0.059)$; AENO $(0.067)$ & $\begin{array}{l}\mathrm{AE}-(0.155) ; \mathrm{AE}=(0.151) ; \\
\mathrm{AE} \#(0.224)\end{array}$ & $\begin{array}{l}\text { AE- }(0.161) ; \mathrm{AE}+(0.141) ; \mathrm{AENO} \\
(0.96)\end{array}$ & $\begin{array}{l}\mathrm{AE}-(0.308) ; \mathrm{AE} /(0.418) ; \\
\mathrm{AE}+(0.496) ; \mathrm{AE}=(0.198) ; \\
\mathrm{AE} \#(0.297) ; \mathrm{AENO}(0.165)\end{array}$ & $\begin{array}{l}\mathrm{AE}+(0.179) ; \mathrm{AE \#} \\
(0.176) ; \mathrm{AENO}(0.085)\end{array}$ & $\mathrm{AE}+(0.165) ; \mathrm{AE} /(0.123)$ \\
\hline \multirow[t]{9}{*}{ KIV } & BOp & B2 (0.162) & B2 $(0.12$ & & B2 $(0.040)$ & B2 (0.122) & B2 $(0.04$ \\
\hline & $\overline{\mathrm{SC}}$ & $\mathrm{SCA}(0.121) ; \mathrm{SCB}(0.120)$ & 8); SCC $(0.124)$ & & $\overline{\operatorname{SCC}(0.040)}$ & SCB $(0.101) ; \operatorname{SCC}($ & $\mathrm{SCB}(0.037)$ \\
\hline & $\overline{\mathrm{FNC}}$ & OHN $(0.129) ;$ OHA $(0.141)$ & OHA $(0.1$ & & & & \\
\hline & $\overline{\mathrm{Cmb}}$ & $\begin{array}{l}\text { CombV4 (0.141); CombX4 } \\
(0.131)\end{array}$ & CombV4 (0.124) & & CombV4 (0.040) & CombV4 (0.122) & CombV4 (0.040) \\
\hline & $\mathrm{pa}$ & Anpa (0.161) & Anpa (0.124) & & Anpa $(0.040)$ & Anpa (0.122) & Awpa (0.022) \\
\hline & TpA & $\begin{array}{l}\text { TpSA (0.142); TpAExpB } \\
(0.119)\end{array}$ & $\begin{array}{l}\text { TpSA (0.108); TPAExpB } \\
(0.090)\end{array}$ & & TрAЕхрB $(0.040)$ & $\mathrm{TpSA}(0.122)$ & TpAExpB (0.037) \\
\hline & $\overline{\mathrm{pAE}}$ & AaNOE $(0.162)$ & AaNOE $(0.124)$ & & $\overline{\mathrm{AaNOE}}(0.040)$ & AaNOE $(0,122)$ & AaNOE $(0.040)$ \\
\hline & An & $\operatorname{ACn}(0.162)$ & $\mathrm{ACn}(0.124)$ & & $\overline{\mathrm{ACn}}(0.040)$ & & $\operatorname{ACn}(0.040)$ \\
\hline & $\overline{\mathrm{AE}}$ & AE\# $(0.162)$ & $\begin{array}{l}\mathrm{AE \#}(0.090) ; \mathrm{AE}-(0.092) ; \\
\mathrm{AE} /(0.090)\end{array}$ & & $\overline{\mathrm{AE}-}(0.040)$ & $\mathrm{AE!}(0.122) ; \mathrm{AE \#}(0.12$ & AE\# $(0.037)$ \\
\hline \multirow[t]{9}{*}{ KV } & BOp & & BOpNO $(0.095)$ & & BOpNO (0.100); B2 (0.138) & BOpNO $(0.085)$ & BOpNO $(0.047)$ \\
\hline & $\overline{\mathrm{SC}}$ & & $\overline{\mathrm{SCA}(0.095)}$ & 20); SCC (0.133) & $\begin{array}{l}\text { SCA }(0.098) ; \text { SCB }(0.138) ; \\
\text { SCNO }(0.009)\end{array}$ & SCA $(0.077)$ & SCA $(0.047)$ \\
\hline & $\overline{\mathrm{FNC}}$ & & $\overline{\mathrm{OHN}}(0.074)$; OHA $(0.074)$ & $\mathrm{OHN}(0.144) ; \mathrm{OHA}(0.223)$ & OHN $(0.138) ;$ OHA $(0.099)$ & OHN (0.077) & OHA $(0.047)$ \\
\hline & $\overline{\mathrm{Cmb}}$ & & $\overline{\text { CombX4 (0.095) }}$ & $\begin{array}{l}\text { CombX4 (0.187); CombV4 } \\
(0.202)\end{array}$ & CombX4 (0.163) & CombX4 (0.085) & CombX4 (0.047) \\
\hline & pa & & Anpa (0.095) & Anpa $(0.213) ;$ Awpa $(0.176)$ & Anpa $(0.138)$; Awpa $(0.098)$ & Anpa (0.085) & Anpa $(0.047)$ \\
\hline & TpA & & $\frac{1}{\mathrm{TpSA}(0.095)}$ & TpSA $(0.223) ;$ TpATip $(0.135)$ & $\begin{array}{l}\text { TpSA (0.146);TpATip } \\
(0.101)\end{array}$ & TpSA $(0.085)$ & TpAExpB $(0.047)$ \\
\hline & $\mathrm{pAE}$ & & AaNOE $(0.095)$ & AaNOE $(0.233)$ & AaNOE $(0.163)$ & AaNOE $(0.085)$ & AaNOE $(0.047)$ \\
\hline & An & & $\overline{\mathrm{ACn}(0.074) ; \mathrm{AAn}}$ & $\operatorname{ACn}(0.233)$ & $\operatorname{ACn}(0.163)$ & $\mathrm{ACn}(0.085)$ & $\operatorname{ACn}(0.047)$ \\
\hline & $\overline{\mathrm{AE}}$ & & 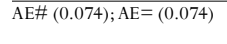 & $\begin{array}{l}\mathrm{AE} \#(0.207) ; \mathrm{AE}+(0.151) ; \mathrm{AE}- \\
(0.179) ; \mathrm{AE}=(0.101)\end{array}$ & $\begin{array}{l}\mathrm{AE \#}(0.098) ; \mathrm{AE}+(0.101) ; \\
\mathrm{AE} /(0.099)\end{array}$ & 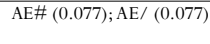 & AE\# $(0.047)$ \\
\hline
\end{tabular}
$(0.179) ; \mathrm{AE}=(0.101) \quad \mathrm{AE} /(0.099)$ 
on gender-based differences (Barkell et al., 2017; Lima et al., 2019), competitive level based differences (Méndez et al., 2019; Yi et al., 2019), or, to a lesser extent, variability in performance within the same competitive level (Castelão et al., 2015; Laporta et al., 2021). This is surprising because inter-team variability is inevitable: teams have their own identities, characteristics, and idiosyncrasies, meaning that within any competitive level there will numerous different ways to approach the game (Ramos, Coutinho, Silva, Davids, \& Mesquita, 2017). Consequently, the overarching objective of the present study was to investigate inter-team variability. Specifically, we aimed to examine this type of variability in high-level men's volleyball during critical game scenarios (i.e., non-ideal setting conditions), using SNA through Eigenvector Centrality.

Our data showed that different teams had distinct ways of approaching the game during critical game scenarios (i.e., non-ideal setting conditions and/or after consecutive attack errors). First, there were differences between the top two ranked teams in side-out attack. Specifically, the USA presented quick attacks on the extremities (mainly zone 4) using both the strong attack and exploration of the block, while under the same conditions Russia presented a game with high attack tempos and strong attack. Second, there were differences in the approach to the game between the top two teams and those ranked third and fourth (Poland and Brazil, respectively) in all complexes, with both Poland and Brazil using varied attack options (between strong attacks, exploration of the block and directed). Third, after one consecutive error in attack, all teams presented a style of play using strong attacks, with only Russia exploring the opposing block (i.e., block-out).

Our findings support previous claims that even at the most elite level of performance the best-ranked teams do not approach the game in the same manner (Ramos, Coutinho, Silva, Davids, \& Mesquita, 2017). Despite some similarities (e.g., the outside hitter was the most requested player in non-ideal setting conditions; the $\mathrm{OH}$ of all teams presented as greater centrality with the strong attack), the elite level teams considered in this study had notable differences in game patterns (e.g., the two best teams had different approaches, with the USA presenting quick attacks in zone 4, using both the strong attack and exploration of the block while Russia presented a game with strong attacks). Thus, our results are consistent with that studied elite men's football (Liu, Gómez, Gonçalves, \& Sampaio, 2016), in that that they provide knowledge of performance differences between teams, translated through distinct game patterns. Furthermore, our results support the idea that there are differences between teams across the various competitive levels because most teams in our study presented a tendency toward strong attacks and few attempts to play in the opponent's error, even after having committed consecutive attacks errors, which contrasts with what has been observed at lower competitive levels by Martins et al. (2021) using a similar protocol.

In addition to the differences observed within the same competitive level, some similarities in inter-team game patterns were also found during critical scenarios. The major similarities identified were: (i) the outside hitter was the most requested player with non-ideal setting conditions; (ii) overall, the $\mathrm{OH}$ of all teams presented a greater centrality with the strong attack; (iii) Brazil and Poland approached the game almost identically in terms of the variables that were analyzed in our study; (iv) both teams not qualifying for the semifinal (France and Iran) had a game model with weaker setting conditions; and (v) Iran, France and Russia had an approach characterized by a predominance of slow attack tempos and strong attacks, both in side-out and transition.

These results indicate that elite-level teams have some similarities in their approaches to the game, with some of these regularities being quite distinct from lower-level teams. However, as we have also shown, even amidst the very top-level teams there are important differences in game patterns, including in how teams approach their attack options when playing under critical game scenarios (e.g., under non-ideal setting conditions and/or after having committed consecutive attack errors). These results imply that forcing a team to adopt a certain game pattern simply because it is used by another team may be ill-advised. Indeed, doing so would reduce variability across teams and thus increase the predictability of performance at the highest competitive levels (Gréhaigne, Bouthier, \& David, 1997). Therefore, match analysis should devote more resources to exploring inter-team variability within the same competitive level or inter-player variability in critical game scenarios.

In addition to these results, SNA again proved its value, allowing to analyze the variability between teams, capturing information from the whole system (team) in order to reveal important patterns (Passos et al., 2011). Due to its flexibility, SNA is a powerful and 
versatile tool in the study of variability, affording an ecological view of the game and players (Chow, Davids, Hristovski, Araújo, \& Passos, 2011; Davids, 2015; Silva, Duarte, Esteves, Travassos, \& Vilar, 2016). Specifically, Eigenvector Centrality aimed to measure the influence of each vertex while weighting both direct and indirect connections (Borgatti, 2005), i.e., it provides a sense of how each node influences the system as a whole.

The coexistence of different game models at the highest levels of performance has consequences for the training process, and for the selection and identification of talents (Vargas et al., 2018); without acknowledging the scope of inter-team variability, naïve, overly simplistic performance models may result in an excessively standardized approach to the game, which will likely not fit many teams. Extending these results further, there may be space for an idiosyncratic approach to each specific $\mathrm{OH}$, i.e., two $\mathrm{OH}$ within the same team may play differently. From the inception of the training process with young athletes, coaches should carefully consider the team features and the individual characteristics, building a dynamic and evolving game model that better promotes these idiosyncratic features, instead of attempting to force a generic performance model.

This study is not without limitations. Statistical methods only go so far, and a more thorough understanding of game performance probably requires the development of more refined variables. A stronger theoretical framework should also be developed, to guide the creation of future observation tools. Alternative statistical methods (i.e., multinomial logistic regression) could be used and compared to different SNA metrics, to provide an understanding of how and where these statistical tools differ. As for the practical implications, studies of this nature may directly influence the coaches' behaviors and help them identify the differences and characteristics between the approaches and game models of the various teams of the same competitive level and thus better study the opponent, as opposed to the idea that at the same level of competition there is only one standardized approach between teams. In this vein, identifying inter-team differences and characteristics also allows coaches to make better decisions in their choices for competitive situations and development of training sessions.

\section{Conclusions}

The present study contributes to the match analysis literature by underlining the importance of studying inter-team variability in game patterns, particularly between teams competing at the same level. That is, the different match models between the teams, allow to find the main game patterns of each team, in order to develop a structure that identifies and defines the specific characteristics of each team (Barrero, Gutiérrez, \& Prieto, 2021). Moreover, this study offers a comparative investigation of teams at the highest competitive level of men's volleyball and a detailed perspective of the game patterns used by teams under pressure. Thus, our results indicate that the analysis of inter-team variability in performance is relevant because it presents a systemic, complex, and ecological perspective of the game.

\section{Declaration of Conflicting Interests}

The authors declare that there is no conflict of interest.

\section{References}

Afonso, J., Mesquita, I., Marcelino, R., \& Silva, J. (2010). Analysis of the setter's tactical action in high-performance women's volleyball. Kinesiology, 42(1), 82-89.

Barkell, F. J., Donna, O., Cotton, G.W., Barkell, J. F., Connor, D. O., \& Cotton,W. G. (2017). Characteristics of winning men's and women's sevens rugby teams throughout the knockout Cup stages of international tournaments Characteristics of winning men's and women's sevens rugby teams throughout the knockout Cup stages of international tourn. International Journal of Performance Analysis in Sport, 16(2), 633-651. https://doi.org/ 10.1080/24748668.2016.11868914

Barrero,A. M., Gutiérrez, I. M., \& Prieto, M. F. (2021). Análisis del modelo de juego en un equipo de fútbol profesional de la Bundesliga de Alemania. Estudio caso (Analysis of the game model in a professional football team in the German First Division. Case study). Retos, 39(39), 628634.https://doi.org/10.47197/RETOS.V0I39.79923

Batista, J., Goncalves, B., Sampaio, J., Castro, J., Abade, E., \& Travassos, B. (2019). The influence of coaches' instruction on technical actions, tactical behaviour, and external workload in football small-sided games. Montenegrin Journal of Sports Science and Medicine, 8(1), 29-36. https: / /doi.org/10.26773/mjssm.190305

Bonacich, P. (2007). Some unique properties of eigenvector centrality. Social Networks, 29(4), 555-564. https:// doi.org/10.1016/j.socnet.2007.04.002

Borgatti, S. P. (2005). Centrality and network flow. Social 
Networks, 27(1), 55-71. https://doi.org/10.1016/ j.socnet.2004.11.008

Castelão, D. P., Garganta, J., Afonso, J., \& Da Costa, I.T. (2015). Análise sequencial de comportamentos ofensivos desempenhados por seleções nacionais de futebol de alto rendimento. Revista Brasileira de Ciencias Do Esporte, 37(3), 230-236. j.rbce. 2015.05 .001

Castellano, J., \& Pic, M.(2019). Identification and preference of game styles in laliga associated with match outcomes. International Journal of Environmental Research and Public Health, 16, 5090. https://doi.org/10.3390/ ijerph16245090

Chow, J.Y., Davids, K., Hristovski, R., Araújo, D., \& Passos, P. (2011). Nonlinear pedagogy: Learning design for selforganizing neurobiological systems. New Ideas in Psychology, 29(2), 189-200. https://doi.org/10.1016/ j.newideapsych.2010.10.001

Costa, G., Mesquita, I., Greco, P. J., Ferreira, N. N., \& Moraes, J. C. (2011). Relação saque, recepção e ataque no voleibol juvenil masculino. Motriz, 17(1), 11-18.https: / /doi.org/ 10.5016/1980-6574.2011v17n1p11

Davids, K. (2015). Athletes and sports teams as complex adaptive system: A review of implications for learning design. Revista Internacional de Ciencias Del Deporte, 39(11), 48-61. https: / / doi.org/10.5232/ricyde2015.03904

Dong, J. G. (2016).The role of heart rate variability in sports physiology (Review). Experimental and Therapeutic Medicine, 11(5), 1531-1536. https://doi.org/10.3892/ etm.2016.3104

Drikos, S., Ntzoufras, I., \& Apostolidis, N. (2019). Bayesian Analysis of Skills Importance inWorld Champions Men's Volleyball across Ages. International Journal of Computer Science in Sport, 18(1), 24 44. https://doi.org/10.2478/ ijcss-2019-0002

Fernández-Echeverria, C., Gil, A., García-González, L., Carrasco Soares, F., Claver, F., \& Del Villar, F. (2013). Employment time-out in volleyball formative stages. Journal of Humam Sport \& Exercise, 8(Proc3), 591-600. https: / / doi.org/10.4100/jhse.2013.8.Proc3.04

Fleiss, J., Levin, B., \& Paik, M. C. (2013). Statistical methods for rates and proportions. Hoboken: John Wiley \& Sons.

Gama, J., Passos, P., Davids, K., Relvas, H., Ribeiro, J., Vaz,V., \& Dias, G. (2014). Network analysis and intra-team activity in attacking phases of professional football. International Journal of Performance Analysis in Sport, 14(3), 692-708. https://doi.org/10.1080/24748668.2014.11868752

Gregson,W., Drust, B., Atkinson, G., \& Salvo, V. D. (2010). Match-to-match variability of high-speed activities in premier league soccer. International Journal of Sports Medicine, 31(4), 237-242. https:/ / doi.org/10.1055/s-00301247546
Gréhaigne, J. F., Bouthier, D., \& David, B. (1997). Dynamicsystem analysis of opponent relationships in collective actions in soccer. Journal of Sports Sciences, 15(2), 137149. https: / /doi.org/10.1080/026404197367416

Gryc, T., Zahalka, F., Maly, T., Mala, L., \& Hrasky, P. (2015). Movement's analysis and weight transfer during the golf swing. Journal of Physical Education and Sport, 15(4), 781787. https: / / doi.org/10.7752/jpes. 2015.04119

Higham, D. G., Hopkins, W. G., Pyne, D. B., \& Anson, J. M. (2014). Performance indicators related to points scoring and winning in international rugby sevens. Journal of Sports Science and Medicine, 13(2), 358-364.

Hill-Haas, S., Coutts, A., Rowsell, G., \& Dawson, B. (2008). Variability of acute physiological responses and performance profiles of youth soccer players in small-sided games. Journal of Science and Medicine in Sport, 11(5), 487490. https://doi.org/10.1016/j.jsams.2007.07.006

Hughes, M., Landridge, C., \& Dawkin, N. (1998). Perturbation leading to shooting in soccer. In M. Hughes \& F. Tavares (Eds.), Proceedings of the Notational Analysis of Sport IVWorld Congress (pp. 33-40). Porto.

Hughes, Mike. (2004). Performance analysis - a 2004 perspective. International Journal of Performance Analysis in Sport, 4(1), 103-109. https://doi.org/10.1080/ 24748668.2004.11868296

Hughes, Mike, \& Franks, I. (2008). The Essentials of Performance Analysis. In Routledge.

Hurst, M., Loureiro, M., Valongo, B., Laporta, L., Nikolaidis, T. P., \& Afonso, J. (2016). Systemic Mapping of HighLevelWomen's Volleyball using Social NetworkAnalysis: The Case of Serve (K0), Side-out (KI), Side-outTransition (KII) andTransition (KIII). International Journal of Performance Analysis in Sport, 16(2), 695-710. https:/ / doi.org/ 10.1080/24748668.2016.11868917

João, P.V., \& Pires, P. M. (2015). Eficácia do Side-out noVoleibol sénior masculino em função do jogador interveniente. Motricidade, 11(4), 142-150. https:/ / doi.org/10.6063/ motricidade. 6302

Laporta, L., Afonso, J., \& Mesquita, I. (2018). Interaction network analysis of the six game complexes in high-level volleyball through the use of Eigenvector Centrality. PLoS ONE, 13(9), 1-14. https://doi.org/10.1371/ journal.pone.0203348

Laporta, L., Afonso, J., Valongo, B., \& Mesquita, I. (2019). Using social network analysis to assess play efficacy according to game patterns: a game-centred approach in high-level men's volleyball. International Journal of Performance Analysis in Sport, 19(5), 866-877. https:/ /doi.org/ 10.1080/24748668.2019.1669007

Laporta, L., Igor,A., Medeiros, A., Vargas, N., Conti, G. De, Costa, T., \& Afonso, J. (2021). Coexistence of Distinct Performance Models in High-LevelWomen's Volleyball. Journal of Human Kinetics, 78(April), 161-173. https: / / 
doi.org/10.2478/hukin-2021-0048

Lima, R., Palao, J. M., Moreira, M., \& Clemente, F. M.(2019). Variations of technical actions and efficacy of national teams' volleyball attackers according to their sex and playing positions. International Journal of Performance Analysis in Sport, 19(4), 491-502. https://doi.org/10.1080/ 24748668.2019.1625658

Liu, H., Gómez, M. A., Gonçalves, B., \& Sampaio, J. (2016). Technical performance and match-to-match variation in elite football teams. Journal of Sports Sciences, 34(6), 509 518. https://doi.org/10.1080/ 02640414.2015 .1117121

Lorenzo-Martínez, M., Rey, E., \& Padrón-Cabo,A. (2019). The effect of age on between-match physical performance variability in professional soccer players. Research in Sports Medicine, 28(3), 351-359. https://doi.org/ 10.1080/15438627.2019.1680985

Marcelino, R., Mesquita, I., \& Sampaio, J. (2011). Effects of quality of opposition and match status on technical and tactical performances in elite volleyball. Journal of Sports Sciences, 29(7), 733-741. https://doi.org/10.1080/ 02640414.2011 .552516

Martins, J. B., Afonso, J., Coutinho, P., Fernandes, R., \& Mesquita, I. (2021). The Attack in Volleyball from the Perspective of Social NetworkAnalysis / : Refining Match Analysis through Interconnectivity and Composite of Variables. Montenegrin Journal of Sports Science and Medicine, 10(1), 45-54. https://doi.org/10.26773/ mjssm. 210307

Mclean, S., Salmon, P. M., Gorman, A. D., Stevens, N. J., \& Solomon, C. (2018). A social network analysis of the goal scoring passing networks of the 2016 European Football Championships. Human Movement Science, 57. https: / / doi.org/10.1016/j.humov.2017.10.001

Méndez, C., Gonçalves, B., Santos, J., Ribeiro, J. N., \&Travassos, B. (2019). Attacking profiles of the best ranked teams from elite futsal leagues. Frontiers in Psychology, 10(1370), 403-414.https://doi.org/10.3389/fpsyg.2019.01370

Millán-Sánchez,A., Morante Rábago, J. C., \& Ureña,A. (2017). Differences in the success of the attack between outside and opposite hitters in high level men's volleyball. Journal of Human Sport and Exercise, 12(2), 251-256. https: / / doi.org/10.14198/jhse.2017.122.01

Passos, P., Davids, K., Araújo, D., Paz, N., Minguéns, J., \& Mendes, J. (2011). Networks as a novel tool for studying team ball sports as complex social systems. Journal of Science and Medicine in Sport, 14(2), 170-176. https: / / doi.org/10.1016/j.jsams.2010.10.459

Project, D. (2019). Instruction Manual DataVolley 4. Bologna: Data Project.

Ramos, A., Coutinho, P., Silva, P., Davids, K., Guimarães, E., \& Mesquita, I. (2017). Entropy measures reveal collective tactical behaviours in volleyball teams: how variability and regularity in game actions influence competitive rankings and match status. International Journal of Performance Analysis in Sport, 17(6), 848-862. https://doi.org/10.1080/ 24748668.2017.1405611

Ramos, A., Coutinho, P., Silva, P., Davids, K., \& Mesquita, I. (2017). How players exploit variability and regularity of game actions in female volleyball teams. European Journal of Sport Science ISSN: , 17(4), 473-481. https: / / doi.org/ 10.1080/17461391.2016.1271459

Sánchez-Moreno, J., Mesquita, I. , Afonso, J., Millán-Sánchez, A., \& Ureña, A. (2018). Effect of the rally length on performance according to the final action and the playing level in high-level men's volleyball. RICYDE: Revista Internacional de Ciencias Del Deporte, 14(52), 136-147. https: / /doi.org/10.5232/ricyde2018.05204

Sarmento, H., Marcelino, R., Anguera, M.T., Campaniço, J., Matos, N., \& Leitão, J. (2014). Match analysis in football: a systematic review. Journal of Sports Sciences, 32(20), 18311843. https://doi.org/10.1080/ 02640414.2014.898852

Silva, P., Duarte, R., Esteves, P., Travassos, B., \& Vilar, L. (2016). Application of entropy measures to analysis of performance in team sports. International Journal of Performance Analysis in Sport, 16(2), 753-768. https://doi.org/ 10.1080/24748668.2016.11868921

Stamm, R., Stamm, M., Torilo, D., Thomson, K., \& Jairus, A. (2016). Comparative analysis of the elements of attack and defence in men's and women's games in the Estonian volleyball highest league. Papers on Anthropology, 25(1), 37. https: / / doi.org/10.12697/poa.2016.25.1.04

Tabachnick, B., \& Fidell, L. (2007). Using multivariate statistics. Boston: Pearson.

Vargas, J., Loureiro, M., Nikolaidis, P.T., Knechtle, B., Laporta, L., Marcelino, R., \& Afonso, J. (2018). Rethinking Monolithic Pathways to Success andTalent Identification: The Case of the Women's Japanese Volleyball Team and Why Height is Not Everything. Journal of Human Kinetics, 64(1), 233-245. https: / / doi.org/10.1515/hukin2017-0197

Wäsche, H., Dickson, G., Woll, A., \& Brandes, U. (2017). Social network analysis in sport research: an emerging paradigm. European Journal for Sport and Society, 14(2), 138165. https://doi.org/10.1080/ 16138171.2017.1318198

Yi, Q., Gómez, M. Á., Liu, H., \& Sampaio, J. (2019).Variation of match statistics and football teams' match performance in the group stage of the UEFA champions league from 2010 to 2017. Kinesiology, 51(2), 170-181. https:// doi.org/10.26582/k.51.2.4 